\title{
Response of Maize (Zea mays $L$ )varieties to planting densities.
}

\author{
Nwokwu Gilbert Nwogboduhu \\ Department of Crop Production and Landscape Management, Faculty of Agriculture and Natural Resources \\ Management, Ebonyi State University, Abakaliki, Nigeria.
}

\begin{abstract}
Field experiments were carried out at the Resreach farm of the Faculty of Agriculture and Natural Resources Management, Ebonyi State University, Abakaliki in 2012 and 2013 cropping seasons. The treatments were three maize varieties and four planting densities and were laid out in a randomized complete block desigen and were replicated three times. Data collected for the two cropping seasons on the growth and yield parameters were pooled and subjected to analysis of variance using a General Linear Model in SAS and Duncan Multiple Range Test was used to separate the treatment means. Results revealed that maize varieties significantly influenced both growth and yield parameters. However, Sammaz17 produced the tallest plants, had more days to tasselling, heaviest 100 seeds, more number of seeds $\mathrm{cob}^{-1}$. Sammaz 17 also was statistically similar with Sammaz 18 in CGR, RGR, LAD, ear height, ear diameter and grain yield. Plant density of 80,000 produced the highest in all the vegetative parameters except in NAR and days to 50\% tasselling while plant density of 60,000 produced the higest grain yield and also was statistically similar with all other plant densities in cob weight and seed number $\mathrm{cob}^{-1}$. Grain yield significantly and postively correlated with all the parameters except with LAD, days to 50\% tasselling and number of cob. Based on the result obtained, it can be concluded that Sammaz 17 should be planted at the planting density of 60,000 by the farmers in the study area.. KeywordsVariety, Density, Zea mays L.
\end{abstract}

\section{Introduction}

Maize (Zea mays L) is one of the most important cereal crops grown in Africa and rank the third most cultivated crop in Nigeria (Ayeni, 1987). The production of this crop has been transformed from that of a minor crop being grown around the homestead to a major or commercial grain crop competing with sorghum and millet as a strategy grain crop in the economy of the nation (Edward et al. 2005). Despite the transformation in the production of this crop, yields of the crop in Nigeria are still below the optima compared to other African countries and beyond. For instance, yield of maize has stagnated at about $1.3 \mathrm{tha}^{-1}$ for a long period compared to near doubling of the world average yield of 2.2 to $3.5 \mathrm{t} \mathrm{ha}^{-1}$ (CIMMYT, 1992).

The reasons for low yield of maize in Nigeria are associated with a number of biotic and abiotic factors; however, it is more affected by variations in plant density than other member of the grass family (Vega et al., 2001). Weather operating directly or indirectly on the plant, biotic factors associated with plant density is one of the most important factors in determing grain yield and other important agronomic attributes of a crop. (Meyer, 1970). This is because the corn plant is less capable of adjustment to a poor stand than other members of the grass family. Some maize varieties especially modern varieties do not tiller much even at low plant densities and very often produce only one ear per plant.Therefore, maize does not have the flexibility of most crop species which can increase leaf area and number of productive units by branching at low crop densities (Gardner et al., 1985).At low densities, many modern maize varieties do not tiller effectively and quite often produce only one ear per plant. Whereas, the use of high population increases interplant competition for light, water and nutrients, which may be detrimental to final yield because it stimulates apical dominance, indices barrenness and ultimately decreases the number of ears produced per plant and kernels set per ear (Sangoi, 2001).

The ways in which Nigeria can record an increase in yield of maize are through breeding and selections of suitable varieties for each ecological zone, use of adequate population density and also very importantly, adoption of adequate cultural practices (Carolene and Roselle, 1987, Fakorode and Kim, 1988). Maize differs in its response to plant density (Luque et al., 2006). Lui et al. (2004) also reported that maize yield differs significantly under varying plant density levels due to differences in genetic potential. Plant populations affect most growth parameters of maize even under optimal growth conditions and therefore it is considered a major factor determining the degree of competition between plants (Sangakkara et al., 2004). The grain yield per plant is decreased in response to decreasing light and other environmental resources available to each plant (Ali et al., 2003). Stand density affects plant architecture, alters growth and developmental patterns and influence carbohydrates production. In each production situation, there is a population that maximizes the utilization of the resources available, especially light, water and nutrients, allowing the production of maximum grain yield. An optimum plant population for maximum economic yield exists for all crop species and varies with cultivars and environment (Bruns and Abbas, 2005). The number of plants per unit area of land depends on the variety, 
its maturity, the productivity of the soil and water supply. Optimum corn population for maximum economic grain yield varies with cultivars, row width, soil fertility and water (Walden, 1977). According to Sangoi, (2001) Maize plant population for maximum economic grain yield varies from 30,000 to 90,000 plants ha ${ }^{-1}$ depending on planting date, water availability, soil fertility and maturity. Improved endurance in high stands has allowed maize to intercept and use solar radiation more efficiently, contributing to the remarkable increase in grain yield potential. Pepper (1974) reported increased plant densities promote utilization of solar radiation by maize canopies. However, efficiency of conversion of intercepted solar radiation into economic maize yield will decrease with high plant density because of mutual shading of plants. Dry matter production in crop plants is directly related to the utilization of solar radiation, which is influenced by canopy structure (Daughtry et al 1983). Tall and leafy cultivars require low densities to maximize grain yield per area (Aldrich et al., 1986). It is also well known that increasing plant densities increases leaf area index and consequently water consumption (Telio-Kagho and Gardner 1988). The use of high population under limited water supply may increase plant stress and reduce grain yield drastically especially if the water shortage coincides with the period of 2-3 weeks of silking (Westgate 1994). Therefore, drought stress particularly when combined with high plant density can cause complete loss of grain production, if stress occurs during the tasseling and silking stage of production (Henero and Johnso, 1981, Edmeades, et al. 1993). Therefore, the objective of this study was determine the effect of planting density on the growth and yield of maize varieties.

\section{Materials and Methods}

The field study was conducted at the Teaching and Research Farm of the Faculty of Agriculture and Natural Resource Management, Ebonyi State University Abakaliki during 2012 and 2013 cropping seasons. The experiment was laid out as $3 \times 4$ factorial in a randomized complete block designwiththree replications.Thetreatments used werethree maize varieties(Sammaz18 (early), Sammaz 17(Medium) and Sammaz 14 (late)) and the four plant densities (20,000 plants ha ${ }^{-1}, 40,000$ plants ha $^{-1}, 60,000$ plant ha $^{-1}$ and 80,000 plants ha $^{-1}$ ) which gave a total of 12 treatment combinations in each replicate. Each plot size was $3 \mathrm{~m} \mathrm{x}$ $3 \mathrm{~m}$ with a net plot size of $2.5 \mathrm{~m} \times 2.5 \mathrm{~m}$ and the plots were separated by a distance of $0.5 \mathrm{~m}$ and the replicates by $1 \mathrm{~m}$. Preplanting herbicides, glyphosate (round up) was applied to the experimental site at the rate $2 \mathrm{~kg}$ a.i. ha ${ }^{-1}$ two weeks before land preparation in each year of the study in order to control the prevalent weeds on the field. Thereafter, the field was harrowed twice to ensure fine tilth of the soil and the soil was demarcated into plots.Planting was done manually on 20th June of both cropping seasons using seeds of the varieties treated with Apron plus 50 DS (a.i $10 \%$ metalaxyl) at a rate of $10 \mathrm{~g}$ per $2 \mathrm{~kg}$ of seeds. Fertilizers were applied at the rate of $120 \mathrm{~kg} \mathrm{~N} \mathrm{ha}^{-1}, 30 \mathrm{~kg} \mathrm{P}_{2} \mathrm{O}_{5} \mathrm{ha}^{-1}$ and $30 \mathrm{~kg} \mathrm{~K}_{2} \mathrm{O}$. The nitrogen fertilizer were applied as split, half of the nitrogen fertilizer together with $30 \mathrm{~kg} \mathrm{P}_{2} \mathrm{O}_{5}$ ha $^{-1}$ and $30 \mathrm{~kg} \mathrm{~K}_{2} \mathrm{O}$ were applied once at two weeks after planting using NPK $(15: 15: 15)$ while the second half of the nitrogen were applied at the tasselling stages using urea $(46 \% \mathrm{~N})$. Weed control was done by pre-emergent application of premetra (Atrazine +Metalachlor) at the rate of $2 \mathrm{~kg} \mathrm{a}^{\mathrm{i}} \mathrm{ha}^{-1}$ immediately after sowing in both years of the study. This was later supplemented by hand weeding using traditional hoe at 7 weeks after Sowing. Data collected for the two cropping seasons on the growth and yield parameters were pooled and subjected to analysis of variance technique using a General Linear Model in SAS and Duncan Multiple Range Test was used to separate the treatment means(Duncan, 1995). Correlation analysis were also performed on the growth parameters, yield andyield components.

\section{Results and Discussion}

Plant height:Almost all the growth parameters were significantly affected by maize varieties and plant densities (Table 1). The tallest plants $(216.73 \mathrm{~cm}$ ) were produced by Sammaz 17, followed by Sammaz 18 $(203.72 \mathrm{~cm})$ which was statistically at par with Sammaz $14(202.37 \mathrm{~cm})$. Plant densities also differed significantly with an increase in height as the plant densities increase from 20,000 to 80,000 plants ha ${ }^{-1}$. The tallest plants were recorded by 80,000 plants ha $^{-1}$, followed by 60,000 plants $^{-1}$ which was statistically at par with 40,000 plant ha ${ }^{-1}$ while the shortest plants were recorded by 20,000 plants $^{-1}{ }^{-1}$. This is due to crowding effect of the plants and higher intra-specific competition for resources. This trend explains that as the number of plants increased in a given area the competition among the plants for nutrients uptake and sunlight interception also increased (Sangakkara et al.,2004).

Number of leaves: The highest number of leaves were produced by Sammaz 17 which were statistically at par with Sammaz 18 and in turn were statistically similar with Sammaz 14. The data regarding plant densities revealed that 80,000 plants $^{-1} a^{-1}$ which were statistically similar with 60,000 plants ha ${ }^{-1}$ recorded the highest number of leaves while 40,000 plants ha $^{-1}$ which were at par with 20,000 plants $\mathrm{ha}^{-1}$ recorded the least number of leaves. Late planting reduced vegetative growth because of less photosynthic activity at later stages of plant growth. Late planting reached the critical day length quickly which terminated vegetative growth resulting in shorter plants with fewer and smaller leaves. Reduction in vegetative growth might have ultimately resulted in lower biomass yield. 
Leaf area index: The highest leaf area index (0.44) was produced by Sammaz 14 followed by Sammaz 17 while the least leaf area $(0.35)$ were produced by Sammaz 18 . The highest leaf area index were recorded by 80,000 plants ha $^{-1}$ while the least leaf area index were recorded by 20,000 plants ha $^{-1}$ which were statistically at par with 60,000 plants ha ${ }^{-1}$. Valadabadi and Farahani (2010) reported that leaf area is influenced by genotype, plant population, climate and soil fertility. They further reported that highest physiological growth indices are achieved under high plant density because photosynthesis increases by development of leaf area. In this research, the increase in LAI explains the general crop trends that increasing plant density increases leaf area index on account of more area. Previous research findings also indicated that in high maize density, leaf area index, total dry weight and crop growth rate increased than low maize density throughout crop growth season (Saberali, 2007).

Physiological indices: There were significant variation among the maize varieties on physiological indices such as crop growth rate (CGR), relative growth rate and leaf area duration except net assimilation rate. Sammaz 17 and 18 produced higher crop growth rate, relative growth rate and leaf area duration than Sammaz 14. However, there were no significant effect among the varieties on net assimilation rate. The data on plant densities revealed that 80,000 plants $\mathrm{ha}^{-1}$ recorded the highest crop growth rate, followed by 20,000 plants ha ${ }^{-1}$ while the least crop growth rate were recorded by 40,000 and 60,000 plants $\mathrm{ha}^{-1}$. The plant densities of 60,000 and 80,000 plants ha ${ }^{-1}$ recorded higer than any other plant densities on net assimilation rate and relative growth rate respectively. However all other plant densities were statistically similar. The highest leaf area duration were recorded by 80,000 plants $\mathrm{ha}^{-1}$, followed by 60,000 plant ha $^{-1}$ which were statistically at par with 40,000 plant $\mathrm{ha}^{-1}$ while the least laef area duration were recorded by 20,000 plant ha ${ }^{-1}$. Crop growth rate depends on the amount of radiation intercepted by the crop and on the efficiency of conversion of intercepted radiation into dry matter. Vigorous vegetative growth, greater dry matter accumulation and photoassimilates partitioning from vegetative to reproductive phase are the main indicators of physiological indices.

Days to 50\% tasselling: Sammaz 14 and 17 took more days to reach 50\% tasselling than Sammaz18 and they were statistically similar. The plant densities had sigificant variation on days to $50 \%$ tasselling. As the plant densities increases the days to $50 \%$ tasselling reduced. The lowest plant density of 20,000 plants ha $^{-1}$ took more days to tassell, followed by 40,000 plant ha $^{-1}$ while the earliest tasselling was observed in the highest plant densities of 80,000 plant $^{-1}{ }^{-1}$. Late maturing varieties took more days to tassel and hence had a better chance to utilize more nutrients and more photosynthetic activity, which utimately resulted in late maturity. The earliest tasselling observed in the highest plant density of 80,000 plants ha ${ }^{-1}$ was due intea-specific competition for soil nutrients, water and sunlight among the plants which utimately triggers the plants to earily reproductive phase while lower plant density utilized soil nutrients, water and solar radiation efficiently thereby prolonged the tasselling dates.

Table 1: Growth parameters of maize varieties as affected by planting densites

\begin{tabular}{|c|c|c|c|c|c|c|c|c|}
\hline Treatments & $\begin{array}{l}\text { Plant } \\
\text { height } \\
(\mathrm{cm})\end{array}$ & $\begin{array}{l}\text { Number } \\
\text { of leaves }\end{array}$ & $\begin{array}{l}\text { Leaf } \\
\text { Area } \\
\text { Index } \\
\end{array}$ & $\begin{array}{l}\text { Crop growth } \\
\text { rate } \\
\left(\mathrm{g} . \mathrm{m}^{2} \mathrm{wk}^{-1}\right)\end{array}$ & $\begin{array}{l}\text { Relative } \\
\text { growth rate } \\
\left(\mathrm{g} . \mathrm{wk}^{-1}\right)\end{array}$ & $\begin{array}{l}\text { Net } \\
\text { assimilation } \\
\text { rate }\left(\text { g.dm }{ }^{2}\right)\end{array}$ & $\begin{array}{l}\text { Leaf area } \\
\text { durationm }{ }^{2} . \mathrm{wk}^{-} \\
1\end{array}$ & $\begin{array}{l}\text { Days } 50 \% \\
\text { tasselling }\end{array}$ \\
\hline \multicolumn{9}{|l|}{ Variety } \\
\hline Sammaz 18 & $203.72 b$ & $14.61 \mathrm{a}$ & $0.35 \mathrm{c}$ & $32.37 \mathrm{a}$ & $0.30 \mathrm{a}$ & $0.03 \mathrm{a}$ & $224.34 a$ & $60.08 \mathrm{~b}$ \\
\hline Sammaz 17 & $216.73 a$ & $14.85 \mathrm{ab}$ & $0.39 \mathrm{~b}$ & $31.99 \mathrm{a}$ & $0.30 \mathrm{a}$ & $0.02 \mathrm{a}$ & $230.05 a$ & $70.67 \mathrm{a}$ \\
\hline Sammaz 14 & $202.37 \mathrm{~b}$ & $14.38 \mathrm{~b}$ & $0.44 a$ & $30.59 \mathrm{~b}$ & $0.26 \mathrm{~b}$ & $0.01 \mathrm{a}$ & $210.72 b$ & $70.33 a$ \\
\hline $\mathrm{SE} \pm$ & 2.03 & 0.15 & 0.001 & 0.26 & 0.003 & 0.001 & 2.68 & 0.49 \\
\hline \multicolumn{9}{|c|}{ Density (Plants ha ${ }^{-1}$ ) } \\
\hline 20,000 & $197.11 \mathrm{c}$ & $13.80 \mathrm{~b}$ & $0.34 \mathrm{c}$ & $32.38 \mathrm{~b}$ & $0.16 b$ & $0.02 \mathrm{~b}$ & $210.81 \mathrm{c}$ & $68.89 \mathrm{a}$ \\
\hline 40,000 & $204.49 \mathrm{~b}$ & $13.76 \mathrm{~b}$ & $0.42 \mathrm{~b}$ & $24.93 c$ & $0.22 b$ & $0.02 \mathrm{~b}$ & $214.85 b c$ & $68.22 b$ \\
\hline 60,000 & $206.40 \mathrm{~b}$ & $15.42 \mathrm{a}$ & $0.34 \mathrm{c}$ & $27.23 \mathrm{c}$ & $0.25 b$ & $0.04 \mathrm{a}$ & $220.59 b$ & $67.67 \mathrm{c}$ \\
\hline 80,000 & $222.42 \mathrm{a}$ & $15.47 \mathrm{a}$ & $0.46 \mathrm{a}$ & $42.05 \mathrm{a}$ & $0.51 \mathrm{a}$ & $0.02 b$ & $240.57 \mathrm{a}$ & $67.35 \mathrm{~d}$ \\
\hline $\mathrm{SE} \pm$ & 2.35 & 0.02 & 0.001 & 0.09 & 0.003 & 0.001 & 3.09 & 0.06 \\
\hline
\end{tabular}

\section{Yield and yield Components}

Yield and yield characters were sigificantly affected by both varieties and plant densities (Table 2). Sammaz 17 and 18 significantly produced higher ear height and ear diameter than sammaz 14 and sammaz 17 inturn was statistically similar with sammaz 14 . Variety had no significant effect on number of cobs. The plant density of 80,000 plant ha ${ }^{-1}$ produced the tallest ear while other plant densites were statistically similar. Increase in plant density from 20,000 to 40,000 plants ha ${ }^{-1}$ resulted an increase in ear diameter and number of cobs but further increase from 60,000 to 80,000 plants $\mathrm{ha}^{-1}$ decreased the ear diameter and number of cobs. The heaviest cob were produced by 60,000 and 80,000 plant ha $^{-1}$ which was statistically at par with 40,000 plant ha ${ }^{-1}$ and 40,000 plants ha $^{-1}$ in turn was similar with 20,000 plants ha $^{-1}$ 
Sammaz 17 produced the heaviest seeds, highest number of seeds per cob and highest yield while sammaz14 were statistically similar with sammaz 18 in these parameters. The heaviest 100 seeds were produced by 40,000 plant ha-1 followed by 20,000 plants ha- 1 which was statistically similar with 60,000 plants ha- 1 while least was produced by 80,000 plants ha- 1 . The plant density of 40,000 plants ha- 1 which were statistically similar with 60,000 and 20,000 plant ha-1 produced higher number of seeds per cob than 80,000 plants ha- 1 . The highest grain yield were significantly produced by 60,000 plants, followed by 80.000 plants while the least significat effect which was statistically similar with 40,000 plants ha- 1 were produced by 20,000 plants ha1.The use of high plant densities may reduce the supply of nitrogen, photosynthates and water to the growing ear height. Also, high stand establishment creates competition for light, aeration, nutrients and consequently compelling the plants to undergo less reproductive growth (Zamir et al.,2011). The increase in number of grains in lower densities might be due to availability of more resources resulting in less competition. When the number of individuals per area is increased beyond the optimum plant density, there is a series of consequences that are detrimental to ear ontogeny that result in barrenness (Sangoi, 2001).The increase in 100 seed weight from 20,000 to 60,000 plants ha-1 might be due to availability of more resources (nutrients +water) for comparatively less number of plants which they utilized efficiently. Low grain weight in high plant population density was probably due to availability of less potosynthates for grain development on account of high inter-specific competition which resulted in low rate of photosynthates and high rate of respiration as a result of enhenced mutual shading (Zamiret al., 2011).

The superior performance of Sammaz 17 could be attributed to its inherent yield potential and its better response to the environmental stress created by the increased plant density. It could be argued that Samaz 17 which is a medium maturing variety was less affected by seasonal fluctuations. Availability of improved varieties with shorter plants, lower leaf number, upright leaves, smaller tassels and reduced anthesis silking interval has enhanced the ability of maize to withstand high plant populations without showing excessive barrenness (Sangoi, 2001).The highest grain yield obtained with plant density of 60,000 ha-1 might be due to large number of plants per $\mathrm{m} 2$ which compensated the effects of decrease in other yield components. These components though decreased per se, yet yield actually increased per unit area. Plants grown with wider spacing consume more nutrients and absorb more solar radiation for efficient photosynthesis and hence perform better at individual basis. The reason for deviation of this linearity in case of grain yield per unit area is that the yield does not solely depend on the performance of individual plant but rather depend on total number of grains per cob and other yield contributing characters. This study revealed that a density of 60,000 plants ha- 1 would be the optimum for maximum grain production for the varieties tested. This is in agreement with Akbar et al.(1996) who reported that optimum plant density produced greater yield due to efficient utilization of available soil nutrients coupled with other growth factors. The lowest grain yield with highest density was due to smaller ear size, less number of ears plant-1due to more competition for growth factors. Porter et al.(1997) suggested that plant distribution was a yield limiting factors when other limiting factors such as nutrient deficiencies were eliminated.

Table 2: Yield and yield components of maize varieties as affected by planting densites

\begin{tabular}{|l|l|l|l|l|l|l|l|}
\hline Treatments & $\begin{array}{l}\text { Ear } \\
\text { height } \\
(\mathrm{CM})\end{array}$ & $\begin{array}{l}\text { Ear } \\
\text { Diameter }\end{array}$ & $\begin{array}{l}\text { Number } \\
\text { of Cobs }\end{array}$ & $\begin{array}{l}\text { Cob } \\
\text { weight } \\
(\mathrm{kg})\end{array}$ & $\begin{array}{l}100 \\
\text { seed } \\
\text { weight(g) }\end{array}$ & $\begin{array}{l}\text { Seed } \\
\text { number } \\
\text { Cob }^{-1}\end{array}$ & $\begin{array}{l}\text { Grain } \\
\text { yield } \\
\left(\mathrm{t} \mathrm{ha}^{-1}\right)\end{array}$ \\
\hline Variety & & & & & & \\
\hline Sammaz 18 & $66.06 \mathrm{ab}$ & $17.69 \mathrm{ab}$ & $4.75 \mathrm{a}$ & $6.48 \mathrm{a}$ & $112.50 \mathrm{~b}$ & $421.17 \mathrm{~b}$ & $3.11 \mathrm{a}$ \\
\hline Sammaz 17 & $67.67 \mathrm{a}$ & $18,06 \mathrm{a}$ & $4.72 \mathrm{a}$ & $6.54 \mathrm{a}$ & $135.42 \mathrm{a}$ & $463.92 \mathrm{a}$ & $4.35 \mathrm{a}$ \\
\hline Sammaz 14 & $64.43 \mathrm{~b}$ & $17.07 \mathrm{~b}$ & $4.79 \mathrm{a}$ & $6.19 \mathrm{a}$ & $100.00 \mathrm{~b}$ & $402.92 \mathrm{~b}$ & $2.61 \mathrm{~b}$ \\
\hline SE \pm & 1.04 & 0.25 & 0.03 & 0.53 & 6.25 & 14.31 & 0.49 \\
\hline Density ( plants ha & & & & & & & \\
\hline 20000 & $65.06 \mathrm{~b}$ & $18.09 \mathrm{a}$ & $5.32 \mathrm{a}$ & $4.89 \mathrm{~b}$ & $119.44 \mathrm{~b}$ & $454.22 \mathrm{a}$ & $2.74 \mathrm{c}$ \\
\hline 40000 & $66.09 \mathrm{~b}$ & $18.60 \mathrm{a}$ & $6.05 \mathrm{a}$ & $6.11 \mathrm{ab}$ & $161,11 \mathrm{a}$ & $473.22 \mathrm{a}$ & $2.63 \mathrm{c}$ \\
\hline 60000 & $66.31 \mathrm{~b}$ & $17.01 \mathrm{~b}$ & $3.82 \mathrm{~b}$ & $7.56 \mathrm{a}$ & $105.56 \mathrm{~b}$ & $440.78 \mathrm{a}$ & $3.90 \mathrm{a}$ \\
\hline 80000 & $66.76 \mathrm{a}$ & $16.72 \mathrm{~b}$ & $3.83 \mathrm{~b}$ & $7.07 \mathrm{a}$ & $77.78 \mathrm{c}$ & $349.11 \mathrm{~b}$ & $3.49 \mathrm{~b}$ \\
\hline SE \pm & 0.12 & 0.03 & 0.31 & 0.06 & 7.20 & 16.50 & 0.06 \\
\hline
\end{tabular}

Means followed by same letter (s) within same column and treatment group are not statistically different at 5\% levelof probability using Duncan Multiple Range Test (DMRT).

\section{Correlation coefficient analysis}

Table 3 show the relationships that exist among the growth, yield and yield characters of the maize varieties. Grain yield significantly and postively correlated with all the parameters except with leaf area duration and days to $50 \%$ tasselling butthe strength of relationship between grain yield and seed number $\operatorname{cob}^{-1}$ were observed to be the highest (0.372).Plant height significantly and positively correlated with all the parameters 
except with net assimilation rate, leave area duration and 100 grain weight . The character with the weakest association with plant height was number of 100 grain weight $(-0.148)$ that was negative and non-significant. Number of leaves significantly and positively correlated with only relative growth rate (0.499) and seed number $\mathrm{cob}^{-1}(0.284)$. Leaf area index significantly correlated with all parameters with the strongest 100 grain weight. $(0.670)$. Crop growth rate significantly correlated with all the parameters except net assimilation rate $(-0.076)$, days to $50 \%$ tasselling $(0.049)$ and cob weight $(0.204)$. Seed number $\operatorname{cob}^{-1}$ significantly and postively correlated with all the parameters. Grain yield significantly and postively correlated with all the parameters except with LAD, days to $50 \%$ tasselling and number of cob.

Table 3: Correlation matrix among growth and yield yield characters of three maize varieties

\begin{tabular}{|c|c|c|c|c|c|c|c|c|c|c|c|c|c|c|}
\hline & 1 & 2 & 3 & 4 & 5 & 6 & 7 & 8 & 9 & 10 & 11 & 12 & 13 & 13 \\
\hline 1 & 1 & & & & & & & & & & & & & \\
\hline 2 & $0.253^{*}$ & 1 & & & & & & & & & & & & \\
\hline 3 & $0.238^{*}$ & $0.336^{*}$ & 1 & & & & & & & & & & & \\
\hline 4 & $0.296^{*}$ & $0.366^{*}$ & 0.185 & 1 & & & & & & & & & & \\
\hline $\begin{array}{l}5 \\
6\end{array}$ & $\begin{array}{l}0.288^{*} \\
0.261^{*}\end{array}$ & $\begin{array}{l}0.379^{*} \\
0.467^{*}\end{array}$ & $\begin{array}{r}0.022 \\
0.499 * *\end{array}$ & $\begin{array}{l}0.659 * 4 \\
0.547 * 4\end{array}$ & $0.459 * *^{1}$ & 1 & & & & & & & & \\
\hline $\begin{array}{l}7 \\
8\end{array}$ & $\begin{array}{l}0.286^{\circ} \\
0.217\end{array}$ & $\begin{array}{l}0.150 \\
0.094\end{array}$ & $\begin{array}{r}-0.011 \\
0.048\end{array}$ & $\begin{array}{l}0.342^{*} \\
-0.342^{*}\end{array}$ & $\begin{array}{l}-0.076 \\
0.574 * *\end{array}$ & $\begin{array}{l}-0.005 \\
0.305 *\end{array}$ & $\begin{array}{r}1 \\
0.043\end{array}$ & 1 & & & & & & \\
\hline $\begin{array}{r}9 \\
10\end{array}$ & $\begin{array}{l}0.185 \\
0.288\end{array}$ & $\begin{array}{l}0.347^{*} \\
0.447^{*}\end{array}$ & $\begin{array}{l}0.067 \\
0.051\end{array}$ & $\begin{array}{l}0.269 * \\
0.633 * 4\end{array}$ & $\begin{array}{l}0.049 \\
0.320 * 4\end{array}$ & $\begin{array}{l}0.231 \\
0.392^{*}\end{array}$ & $\begin{array}{r}0.287 * \\
0.182\end{array}$ & $\begin{array}{l}0.365^{*} \\
0.654^{* *}\end{array}$ & $\begin{array}{r}1 \\
.0 .066\end{array}$ & & & & & \\
\hline 11 & $0.316^{*}$ & -0.148 & -0.184 & $0.670 * 4$ & $0.606 * 4$ & $0.473^{*}$ & -0.170 & $0.652 * 4$ & $0.340^{*}$ & 0.521 & 1 & & & \\
\hline $\begin{array}{l}12 \\
13 \\
\end{array}$ & $\begin{array}{l}0.333 * \\
0.372 *\end{array}$ & $\begin{array}{l}0.277^{*} \\
0.300^{*}\end{array}$ & $\begin{array}{l}0.049 \\
0.284^{4}\end{array}$ & $\begin{array}{l}0.317^{*} \\
0.407^{*}\end{array}$ & $\begin{array}{l}0.204 \\
0.562 * *\end{array}$ & $\begin{array}{l}0.149 \\
0.620 * 4\end{array}$ & $\begin{array}{l}0.072 \\
0.040\end{array}$ & $\begin{array}{l}0.128 \\
0.649 *\end{array}$ & $\begin{array}{l}-0.021 \\
0.438 * \\
\end{array}$ & $\begin{array}{l}0.470^{*} \\
0.470^{*}\end{array}$ & $\begin{array}{r}-0.047 \\
0.562 * * \\
\end{array}$ & $\begin{array}{l}1 \\
-0.021\end{array}$ & 1 & 1 \\
\hline \multicolumn{4}{|c|}{$\begin{array}{l}\text { I=Grain yield } \\
2 \text {-plant height }\end{array}$} & \multicolumn{4}{|c|}{$\begin{array}{l}5=\text { Crop growth rate } \\
6 \text {-Relative growth rate }\end{array}$} & \multicolumn{7}{|c|}{$9=$ Days to $50 \%$ tasselling } \\
\hline \multicolumn{4}{|c|}{$3=$ Number of leaves } & \multicolumn{4}{|c|}{$7=$ Net assimilation rate } & \multicolumn{7}{|c|}{$11=100$ grain weight } \\
\hline \multicolumn{4}{|c|}{$4=$ Leaf area index } & \multicolumn{4}{|c|}{$8=$ Leaf area duration } & \multicolumn{7}{|l|}{$12=\mathrm{Cw}$} \\
\hline \multicolumn{4}{|c|}{$* 4=$ significant at $1 \%$} & \multicolumn{4}{|c|}{$*=$ significant at $5 \%$} & \multicolumn{7}{|l|}{$13=\$ \mathrm{NC}$} \\
\hline
\end{tabular}

\section{Conclusion}

It could be concluded from the present study that maize varieties should be cultivated according to the areas of their adaptability for increased grain and biomass yield per unit area. The study further indicated that Sammaz 17 should be planted at the planting density of 60,000 plants ha ${ }^{-1}$ by the farmers in the study area.

\section{References}

[1]. Akbar, H. P. Shah, A.Z. Khan, H Saeed and M Munir.1996. Biomass, grain yield and harvest Index as criteria for comparing corn types at different nitrogen levels and planting densities. Sarhad Journal of Agriculture 12:117-121.

[2]. Aldrich, S.R., Scoh, W.O and Hoeft, R.C. 1986. Modern corn production. Champaign: A and DPublication, 386p.

[3]. Ali, R., S.K Khalil, S.M. Raza and H. Khan. 2003. Effect of herbicides and row spacing on Maize. Pak. J.Weed Science Res. 9 (3-4) 171-178.

[4]. Ayeni, A.O 1987. Maize production in Nigeria. Problems and prospects. J.Fd. Agric 2:123-129Bruns, H.A and H.K Abbas. 2005. Utra-high plant population and nitrogen fertility effects on Corn in the Mississippi valley. Agronomy Journal 99(4) 1136.

[5]. Caroline, M.R and W.A. Russelle. 1987. Response of plant densities and N values for maize Cultivars from different areas of breeding. Crop Science 27:465-470.

[6]. CIMMTY 1992. World maize facts and trends report: An analysis of changes in production, Consumption, trade and practices over the last two decades, Mexico D.F. Mexico.

[7]. Daughtry, C.S.T., K.P.Gallo and M.E. Bauer. 1983.Spectral estimate of solar radiation in intercepted by corn canopies. Agron. J. 72: 527-531.

[8]. Duncan, D.B 1995. Multiple ranges and multiple F-tests. Biometrics 11:1-42Edmeaders, G.O., Bolanos, J., Latffite 1993. A>R progress in breeding for drought tolerance in Maize: In Annual corn and sorghum Research Conference 47, 93 Chicago. ProceedingChicago, 1993, 93-111.

[9]. Edwards, J.T., L.C. Purcell and E.D. Vories .2005. Light interception and yield potential of Short season maize hybrids in the Midsouth. Agron. J. 97:225-234.

[10]. Fakorede, M.A.B., S.K. Kim., J.H. Mareck and J.E. Iken .1989. Breeding strategies and potential of available varieties in relation to alternating self-sufficiency in maize production in Nigeria. Presented at National Symposium "Towards the attainment of

[11]. Self sufficiency of maize production in Nigeria 9th March, 1989 IAR and T. Ibadan.

[12]. Gardner, F.P., Pearce, R.B., Mttchell, R.L .1985. Physiology of crop plants. Armes. Iowa State University press 1985-4780p.

[13]. Herrero, M.P and Johnson.R. R .1981. Drought stress and its effects on maize reproductivesystem. Crop Science Madison, 21(1) 105-110.

[14]. Lui, W., Tollenaar and G.Smith. 2004.Within row plant spacing variability does not affect cornyield. Agron. J. 96:275-280.

[15]. Luque, S.F., A.G. Cirilo and M.E.Otegui .2006. Genetic gains in grain yield and related Physiological attributes in Argentine maize hybrids. Field crop Res.95:383-397.

[16]. Meyer, D.W. 1970. Use of male sterility for increasing the population tolerance of crop (Zea mays L). Ames. Iowa State University Ph.D Dissertation. Univ. Microfilm order.

[17]. Pepper, G.E. 1974. Effect of leaf orientation and density on the yield of maize. Ph.D. thesis.

[18]. Iowa State University. Ames, Iowa (USA). 
[19]. Porter, P.M, D.R.Hicks, W.E.Lueschen, J.H .Ford, D.D.Warnes and T.R.Hovertad, 1997. Cornresponse to row width and plant populations in the northern corn belt. J.Prod. Agric.10: 293-300.

[20]. Sangakkara, U.R., P.S.R.D. Bandaranayake., J.N.Gajanayake and P. Stamp 2004. Plant Population and yield of rain fed maize grown in wet and dry seasons of the tropics. Maydica.49:83-88.

[21]. Sangoi, L. 2001. Understanding plant density effects on maize growth and development: Animportant issue to maximize grain yield. Ciencia Rural. 31 (1):159-168.

[22]. Telio-kagho, F and Gardner, F.P. 1988. Response of maize to plant population density. In Canopy development, light relationship and vegetative growth. Agronomy journal,Madison 80 (5) 930-935.

[23]. Valadabadi S.A. and H.A.Farahani .2010.Effect of planting density and pattern on physiological growth indices in maize (Zea maysL) under nitrogenous fertilizer application. J. Agric. Ext. and Rural Dev.2 (3):40-47.

[24]. Vega, C.R.C., F. H. Andrade and V.O. Sadras 2001. Reproductive partioing and seed set efficiency in soybean, sunflower and maize. Field crop Res.72:165-173

[25]. Walden, D.B 1977. Maize breeding and genetics. Pp41.

[26]. Westgate, M.E 1994. Seed formation in maize during drought. In: Boote, K.J., Bennet, J.M., Saberali S.F. 2007.Influence of plant density and planting pattern of corn on its growth and yield under competition with common Lambesquarters (Chenopodium album L).Pajouhesh and Sazandegi 74:143-152.

[27]. Sinclair, T.R., Paulses, G.M (Eds). Physiology and determination of crop yield. Madison: American Society of Agronomy. 361-364.

[28]. Zamir M.S.I, A.H. Ahmad, H.M.R.Javeed and T.Latif .2011. Growth and yield behaviour of two maize hybrids (Zea mays .L) towards different plant spacing. Cercetari Agronomice in Moldova.14 (2):33-40. 